\title{
Quality of Life and Depressive Symptoms in Female Models
}

\author{
Salime Donida Chedid Lisboa', Rodrigo Sudatti Delevatti1,2, Ana Carolina Kanitz ${ }^{1,3}$, \\ Felipe Barreto Schuch ${ }^{1,4}$, Cláudia Gomes Bracht1, Luiz Fernando Martins Kruel1 \\ ${ }^{1}$ Universidade Federal do Rio Grande do Sul, Porto Alegre, Brazil \\ ${ }^{2}$ Faculdade Sogipa de Educação Física, Porto Alegre, Brazil \\ ${ }^{3}$ Universidade Federal de Uberlândia, Uberlândia, Brazil \\ ${ }^{4}$ Unilasalle, Canoas, Brazil \\ Email: sa.lisboa@hotmail.com
}

Received 14 July 2016; accepted 9 August 2016; published 12 August 2016

Copyright (C) 2016 by authors and Scientific Research Publishing Inc.

This work is licensed under the Creative Commons Attribution International License (CC BY).

http://creativecommons.org/licenses/by/4.0/

c) (7) Open Access

\section{Abstract}

The purpose of the present study was to analyze quality of life (QoL) levels and depressive symptoms in female models in comparison to non-models. The study was conducted in Estação Saúde Gym, in Caxias do Sul, Rio Grande do Sul, Brazil. The sample of the study was composed of ten runaway and/or commercial female models between the ages of 15 and 25 from Cast One Models agency and eight control adolescent and young adult students from public/private schools and universities, all from Caxias do Sul, Rio Grande do Sul, Brazil. Quality of life and depressive symptoms of all participants were evaluated. Data were described by mean and standard deviation values. The main results were analyzed by independent $t$-test for comparison between models and non-models, adopting a significance level $(\alpha)$ of 0.05 . No differences were found between the groups in the analyzed variables $(p>0.05)$. The results of our study, suggest that professional runaway and commercial female models have similar QoL and depressive symptoms when compared to their control counterparts.

\section{Keywords}

Models, Health, Depressive Symptoms, Quality of Life

\section{Introduction}

Adolescence is comprised between the age group from 10 and 19 years old [1], phase of life which is characterized by several changes in social, cultural and economic fields [2]. A great attention to questions related to 
physical and mental wellbeing, such as weight changes and depressive symptoms are essential, in order to provide a healthy adulthood. In this period, physical size and body shape become issues of concern for adolescents, because leanness has a big tendency for acceptance before society. Besides that, there are some professions with particular physical requirements, like athletes, ballet dancers and models, which are often charged by a rigid maintenance and/or weight loss, which may thus become risk professions [3] [4].

These requirements in relation to physical characteristics, exalting certain default appearance is something common in our society [5]. In this context, women are more susceptible to the changes, in the pursuit of what is considered perfect, which many times contrasts with the ideal of health [6]. In this perspective, an "optimal” female body has been shown by the media, primarily symbolizing by female models, characterized by compulsory body measures, which are extremely strict and provide an idea of patterned and correct body image [7].

Professional models use their appearance to represent products and brands, through advertisements and events [8]. This need for the body to have certain measures, associated to a difficult career, with family removal and sometimes exacerbated focus on glamour may expressively impact on lifestyle, on depressive symptoms and on quality of life (QoL). However, to our knowledge, these outcomes have not been investigated in models. Although recent studies [9] have been emerging investigating the role of model profession on physical health (body composition, physical fitness and dietary intake), the role of the lifestyle followed by professional models on depressive symptoms and QoL are unclear. Thus, the purpose of the present study was to compare depressive symptoms and QoL levels between female models and their non-models counterparts.

\section{Methods}

\subsection{Subjects}

The sample of the study was composed by runaway and/or commercial female models between the ages of 15 and 25 from Cast One Models agency from the city of Caxias do Sul, Rio Grande do Sul, Brazil and also by adolescent and young adult students from public/private schools and universities from Caxias do Sul, Rio Grande do Sul, Brazil. The sample of the study was selected by convenience, being made contact with 16 models from Cast One Models agency, in which 10 accepted to participate in the study (MG). After the selection of the models, a total of 8 non model girls were invited to participate in the study, of which 8 accepted it and were part of the study (NM). These girls were also selected by convenience, in compliance with the same age group and homecity of the models, only avoiding the inclusion of obese girls, by believing that this would generate a huge comparative bias, once obesity is associated to depressive symptoms and poor QoL.

\subsection{Procedures}

Data were collected in a single day. Participants filled in the quality of life (QoL) and depressive symptoms instruments, along with an anamnesis record and an informed consent form. All the data collections were accomplished at EstaçãoSaúde gym in Caxias do Sul, Rio Grande do Sul, Brazil. The reading and the signature of the consent form were individually made (for girls over the age of 18 years) and with the company of those responsible for them (for girls under the age of 18). An assent form was also filled to secure agreement between the study and the locals of the subjects' recruitment.

\subsection{Depressive Symptoms}

Depressive symptoms were evaluated using the Portuguese version of the Depression Escale CES-D [10]. This instrument is self-applicable, trans cultural, consisting of 20 statements, each one had four possible responses corresponding to the numbers $1,2,3$ and 4 . The score ranges from 0 to 60 . Higher scores mean an increased level of depressive symptoms.

\subsection{QoL}

QoL was assessed using the World Health Organization Quality of Life-Bref (WHOQOL-BREF) [1]. The WHOQOL-BREF is a self-assessment, 26-item, short version of the WHOQOL-100 instrument. The results are presented in four domains (physical, psychological, social relation ships, and environment) with scores ranging from 0 to 100 (0 indicates the worst QoL and 100 better QoL). The WHOQOL-BREF has excellent psychome- 
tric proprieties and was transculturally adapted and validated for the Brazilian population [11] (Supplementary Material).

\subsection{Statistical Analysis}

As descriptive statistics the mean and standard deviation values were used. Categorical variables were presented by the sample $n$. The normality and homogeneity of the data were evaluated by the Shapiro-Wilk and Levene tests, respectively. For the comparison between the variables of the models and the non models the independent t-test was used. When comparing categorical variables, we used Fisher's exact test. It was adopted a 5\% significance level. All analyzes were performed using SPSS program, version 20.0.

\section{Results}

\subsection{Flow of Participants}

Twenty-four girls were contacted, 16 of them were models and eight were non models. A total of six subjects left the study, all of the MG (three because of time constraints, one due family problems, one refused to participate and one because of address change). In this way, the final population of the study consisted of 18 subjects (MG; $n=10$ and NM; n = 8). In Figure 1, the flowchart of the individuals over the study can be visualized.

\subsection{Participants}

All the girls who proposed to participate in the study were born and created in the same region, frequenting similar places. In MG, all the models were contracted by the same agency, despite from different backgrounds (regional, national and international models). It is noteworthy to mention the great importance that the MG components gave to the collection of the data (a large number of the models performed the collection procedures in order to obtain more information about their health status). In the same way, the non models participated in the study in order to obtain information that would favor their health and QoL.

\subsection{Sample Characterization}

The characterization of the final sample (analyzed subjects) is presented on Table 1.

\subsection{QoL}

General QoL and in physical health, psychological health, social relationships and environment domains did not show differences between groups ( $\mathrm{p}>0.05)$. These analyses are demonstrated on Table 2 .

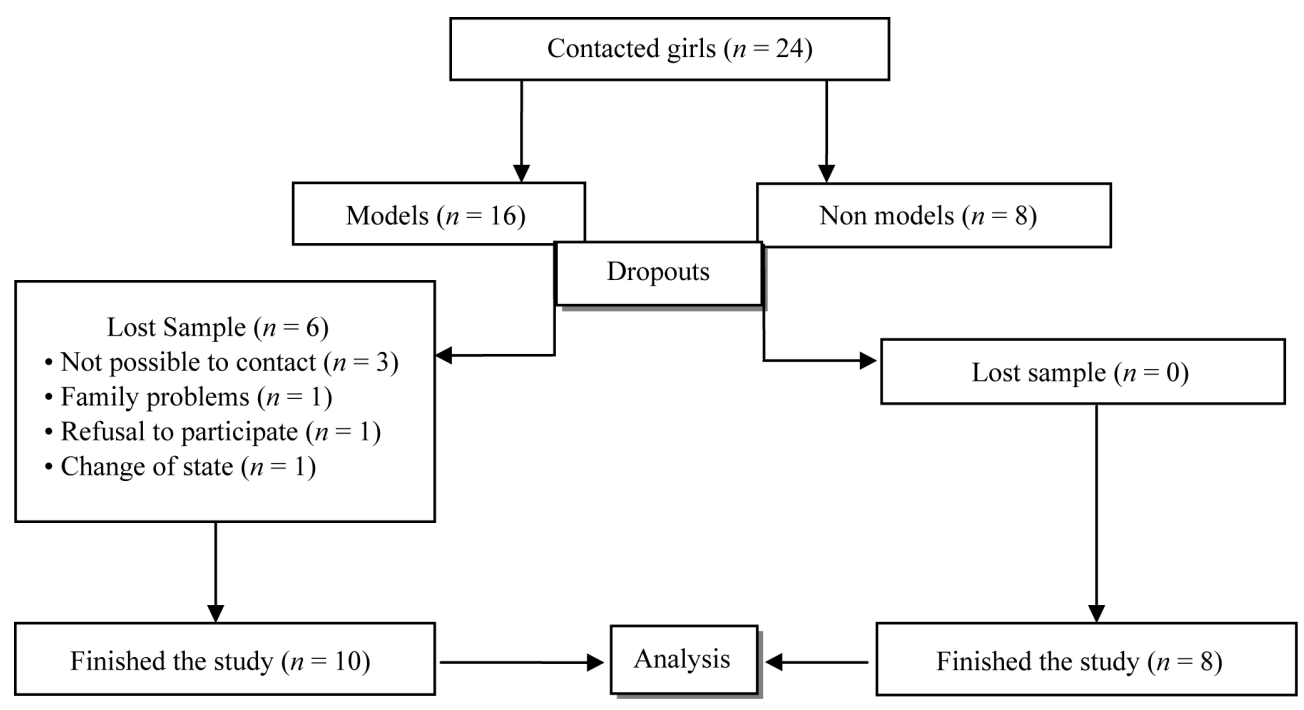

Figure 1. Flow of participants. 


\subsection{Depressive Symptoms}

As well as in QoL, no differences were found between the groups in relation to depressive symptoms ( $\mathrm{p}>0.05)$. These analyses are demonstrated on Table 3.

\section{Discussion}

In general, our results demonstrate that the simple fact of being a model does not implicate in a lower QoL or in a greater number of depressive symptoms, because girls of a same age group and region seem to have these outcomes in a similar number, despite the different labor routine.

Table 1. Sample characterization.

\begin{tabular}{ccc}
\hline & MG $(n=10)$ & NM $(n=8)$ \\
\hline Age (years) & $20.5(16.2-21.7)$ & $21.5(20.2-23.0)$ \\
Career Duration (months) & $49.8 \pm 30.7$ & 2 \\
Nutritional monitoring & 2 & 4 \\
Psychiatric monitoring & 3 & 0 \\
Education & & 0 \\
Incomplete Elementary School & 0 & 0 \\
Complete Elementary School & 0 & 1 \\
Incomplete High School & 3 & 6 \\
Complete High School & 2 & 1 \\
Incomplete Higher Education & 5 & 0 \\
Complete Higher Education & 0 & \\
\hline
\end{tabular}

Age data are presented as median and inter quartile range; Career duration is presented as mean $\pm \mathrm{SD}$; other variables are presented by $n$ of each group.

Table 2. General QoL and in physical, psychological, social relationships and environment domains for the models group (MG) and non models (NM) assessed using WHOQOL-BREF.

\begin{tabular}{cccc} 
& GM $(n=10)$ & NM $(n=8)$ & p value \\
\hline General quality of life & $72.50 \pm 15.37$ & $71.88 \pm 11.08$ & $\mathrm{p}=0.989$ \\
Physical domain & $74.99 \pm 11.41$ & $75.89 \pm 13.73$ & $\mathrm{p}=0.882$ \\
Psychological domain & $67.08 \pm 14.25$ & $71.35 \pm 12.28$ & $\mathrm{p}=0.512$ \\
Social relationship domain & $71.87 \pm 18.33$ & $76.66 \pm 16.10$ & $\mathrm{p}=0.563$ \\
Environment domain & $64.37 \pm 9.22$ & $63 \pm 8.17$ & $\mathrm{p}=0.868$ \\
\hline
\end{tabular}

Data are presented as mean \pm SD. $\alpha$ : 0.05. Analysis was made using independent t-test.

Table 3. Depressive symptoms for the models group (GM) and non models (NM) using CES-D instrument.

\begin{tabular}{llll} 
& $\mathrm{GM}(n=10)$ & $\mathrm{NM}(n=8)$ & Valor de $p$ \\
\hline Depressive symptoms & $19.00 \pm 7.43$ & $15.87 \pm 8.60$ & $\mathrm{P}=0.442$ \\
\hline
\end{tabular}

Data are presented as mean \pm SD. $\alpha$ : 0.05 . Analysis was made using independent t-test. 
The results obtained in our study corroborate the findings of Pires et al. [2], who evaluating QoL in professional adolescent models also found levels of general QoL, physical, social relationships and environment domains similar to the non models. Different from our results, Pires et al. [2] found a greater quality of life in the psychological domain in the models in comparison to the non models.

The results are somehow surprising, because the model profession has particularities of substantial impact on people's daily lives, like family removal, daily pressures, body exposure and high competiveness, which lead us to think in a possible deterioration of the QoL. However, even with these particularities, QoL does not seem to be impaired.

In relation to depressive symptoms, the lack of difference between the groups is also a positive factor to those girls who wish to begin or are working in the model career. Besides these results are in accordance with results found for QoL, they also show similar behavior to physical fitness related to health [9]. Although there are missing studies with this population analyzing the association between these different outcomes, there are some evidences [12] relating physical fitness components, like $\mathrm{VO}_{2 \max }$, to depressive symptoms. Still in this direction, the study of Fleck et al. [11] using the same instrument applied in this study (CES-D) found inverse association between depressive symptoms and several indicators of health and wellbeing of Brazilians. This lead us to the reflection that far beyond labor particularities, habits related to physical exercise, nutrition, as well as genetic component can play an important role in the mental health of these girls.

However, caution should be exercised in interpreting the depressive symptoms results, because in spite of the lack of statistical difference, the mean value of the MG is presented a little higher than the mean values of the NM. Also, the CES-D cut-off for presence of increased depressive symptoms is 11, and both the MG and the NM are above this cut-off. Thus, we claim for the need for care about this outcome.

\section{Conclusion}

Based on the results of our study, model profession seems to not significantly interfere on QoL and on depressive symptoms. Yet, even considering these results as positive for those girls who are inserted or wish to be within this fashion world, more studies with models are necessary to a better understanding about the relationship between this profession and aspects related to health.

\section{Limitations, Strengths and Future Perspectives}

The present study has some limitations. The small number of participants, the fact that all models are from the same agency are the main limitations of, despite of the different professional levels. Therefore future studies should expand the research about this universe in order to obtain a clearer understanding on mental health of professional levels. However, we believe that this study has innovative character for the originality of the proposal, investigating clinically relevant outcomes in a population very little studied. The main strength of the present study is the fact that the women that composed the non model group were from the same socio-cultural context (living in neighborhood with similar socio economical characteristics), and same age than our model group.

\section{References}

[1] The WHOQOL Group (1995) The World Health Organization Quality of Life Assessment (WHOQOL): Position Paper from the World Health Organization. Social Science \& Medicine, 41, 1403-1410. http://dx.doi.org/10.1016/0277-9536(95)00112-K

[2] Pires, L., Rodrigues, A.M., Fisberg, M., Costa, R.F. and Schoen, T.H. (2012) Quality of Life of Adolescent Professional Models. Psicologia: Teoria e Pesquisa, 28, 71-76. http://dx.doi.org/10.1590/S0102-37722012000100009

[3] Braggion, G.L., Matsudo, S.M.M. and Matsudo, V.K.R. (2000) Food Consumption, Physical Activity and Perception of the Body Appearance in Adolescents. Revista Brasileira Ciência e Movimento Brasília, 8, 15-21.

[4] Rodrigues, A.M., Costa, R.F. and Fisberg, M. (2008) Anthropometric Characteristics of Candidates of a Selective Competition of a Big Agency from São Paulo. Centro de Estudos e PesquisaSanny.

[5] Bohm, C.C. (2004) Um peso, umamedida: O padrão de belezafemininaapresentadoportrêsrevistasbrasileiras. [Trabalho de conclusão de curso]. Uniban, São Paulo, 19-27.

[6] Moreira, M.C.M. (2009) Entre a estética do corpo da moda e do corpo do culturismo, estudoexploratório a partir da opinião de manequins e de praticantes de culturismo [tese de mestrado]. Faculdade de Desporto da Universidade do 
Porto, Ciências do Desporto, Porto.

[7] Libardi, M. (2004) Model Profession: In Search of Fame. SENAC SP, São Paulo.

[8] Pascolato, C. and Lacombe, M. (2003) How to Become a Successful Model-What It Is and How You See.

[9] Lisboa, S.D.C., Delevatti, R.D., Kanitz, A.C., Reichert, T., Bracht, C.G., Vieira, A.F. and Kruel, L.F.M. (2016) HealthRelated Physical Fitness in Female Models. Health, 8, 163-172. http://dx.doi.org/10.4236/health.2016.82019

[10] Batistoni, S.S.T., Neri, A.L. and Cupertino, A.P.F.B. (2007) Validade da escala de depressão do Center for Epidemiological Studies entre idosos brasileiros. Revista de Saúde Pública, 41, 598-605. http://dx.doi.org/10.1590/S0034-89102007000400014

[11] Fleck, M.P.A. (2002) O instrumento de avaliação de qualidade de vida da Organização Mundial da Saúde (WHOQOL100): Características e perspectivas. Ciência \& Saúde Coletiva, 5, 33-38.

[12] Papasavvas, T., Bonow, R.O., Alhashemi, M. and Micklewright, D. (2016) Depression Symptom Severity and Cardiorespiratory Fitness in Healthy and Depressed Adults: A Systematic Review and Meta-Analysis. Sports Medicine, 46, 219-230. http://dx.doi.org/10.1007/s40279-015-0409-5 


\section{Supplementary Material}

\section{WHOQOL-ABREVIADO (FLECK et al. 2000)-Versão em Português}

Instruções

Este questionário é sobre como você se sente a respeito de sua qualidade de vida, saúde e outras áreas de sua vida. Por favor, responda a todas as questões. Se você não tem certeza sobre que resposta dar em uma questão, por favor, escolha entre as alternativas a que lhe parece mais apropriada. Esta, muitas vezes, poderá ser sua primeira escolha.Por favor, tenha em mente seus valores, aspirações, prazeres e preocupações. Nós estamos perguntando o que você acha de sua vida, tomando como referência as duas últimas semanas. Por exemplo, pensando nas últimas duas semanas, uma questão poderia ser:

\begin{tabular}{|c|c|c|c|c|c||}
\hline & nada & muito pouco & médio & muito & completeamente \\
\hline $\begin{array}{c}\text { Você recebe dos outros o apoio } \\
\text { de que necessita? }\end{array}$ & 1 & 2 & 3 & 4 & 5 \\
\hline
\end{tabular}

Você deve circular o número que melhor corresponde ao quanto você recebe dos outros o apoio de que necessita nestas últimas duas semanas. Portanto, você deve circular o número 4 se você recebeu "muito” apoio como abaixo.

\begin{tabular}{||c|c|c|c|c|c|}
\hline & nada & muito pouco & médio & muito & completeamente \\
\hline $\begin{array}{c}\text { Você recebe dos outros o apoio } \\
\text { de que necessita? }\end{array}$ & 1 & 2 & 3 & 4 & 5 \\
\hline
\end{tabular}

Você deve circular o número 1 se você não recebeu “nada” de apoio.

Por favor, leia cada questão, veja o que você acha e circule no número e lhe parece a melhor resposta.

\begin{tabular}{||c|c|c|c|c|c|c||}
\hline \hline & muito ruim & ruim & $\begin{array}{c}\text { nem ruim } \\
\text { nem boa }\end{array}$ & boa & muito boa \\
\hline 1 & $\begin{array}{c}\text { Como você avaliaria sua } \\
\text { qualidade de vida? }\end{array}$ & 1 & 2 & 3 & 4 & 5 \\
\hline
\end{tabular}

\begin{tabular}{||c|c|c|c|c|c|c||}
\hline & & $\begin{array}{c}\text { muito } \\
\text { insatisfeito }\end{array}$ & insatisfeito & $\begin{array}{c}\text { nem satisfeito } \\
\text { nem insatisfeito }\end{array}$ & satisfeito & muito satisfeito \\
\hline 2 & $\begin{array}{c}\text { Quão satisfeito(a) você está } \\
\text { com a sua saúde? }\end{array}$ & 1 & 2 & 3 & 4 & 5 \\
\hline
\end{tabular}

As questões seguintes são sobre o quanto você tem sentido algumas coisas nas últimas duas semanas.

\begin{tabular}{||c|c|c|c|c|c|c||}
\hline \hline 3 & $\begin{array}{c}\text { Em que medida você acha que sua dor } \\
\text { (fisica) impede você de fazer } \\
\text { o que você precisa? }\end{array}$ & 1 & muito pouco & mais ou menos & bastante & extremamente \\
\hline 4 & $\begin{array}{c}\text { O quanto você precisa de algum } \\
\text { tratamento médico para levar } \\
\text { sua vida diária? }\end{array}$ & 1 & 2 & 4 & 5 \\
\hline 5 & O quanto você aproveita a vida? & 1 & 2 & 3 & 4 & 5 \\
\hline 6 & $\begin{array}{c}\text { Em que medida você acha que a } \\
\text { sua vida tem sentido? }\end{array}$ & 1 & 2 & 3 & 4 & 5 \\
\hline 7 & O quanto você consegue se concentrar? & 1 & 2 & 3 & 4 & 5 \\
\hline 8 & $\begin{array}{c}\text { Quão seguro(a) você se sente } \\
\text { em sua vida diária? }\end{array}$ & 1 & 2 & 3 & 4 & 5 \\
\hline 9 & $\begin{array}{c}\text { Quão saudável é o seu ambiente fisico } \\
\text { (clima, barulho, poluição, atrativos)? }\end{array}$ & 1 & 2 & 3 & 4 \\
\hline
\end{tabular}


As questões seguintes perguntam sobre quão completamente você tem sentido ou é capaz de fazer certas coisas nestas últimas duas semanas.

\begin{tabular}{||c|c|c|c|c|c|c||}
\hline \hline 10 & nada & muito pouco & médio & muito & completamente \\
\hline 11 & $\begin{array}{c}\text { Você tem energia suficiente } \\
\text { para seu dia-a-dia? }\end{array}$ & 1 & 2 & 3 & 4 & 5 \\
\hline 12 & $\begin{array}{c}\text { Você é capaz de aceitar sua } \\
\text { aparência fisica? }\end{array}$ & 1 & 2 & 3 & 4 & 5 \\
\hline 13 & $\begin{array}{c}\text { Você tem dinherio suficiente para } \\
\text { satisfazer suas necessidades? }\end{array}$ & 1 & 2 & 3 & 4 & 5 \\
\hline $\begin{array}{c}\text { Quão dispoíveis para você estão as } \\
\text { infromações que precisa no seu dia-a-dia? }\end{array}$ & 1 & 2 & 3 & 4 & 5 \\
\hline 14 & $\begin{array}{c}\text { Em que medida você tem oportunidades } \\
\text { de atividade de lazer? }\end{array}$ & 1 & 2 & 3 & & 5 \\
\hline
\end{tabular}

As questões seguintes perguntam sobre quão bem ou satisfeito você se sentiu a respeito de vários aspectos de sua vide nas últimas duas semanas.

\begin{tabular}{||l|c|c|c|c|c|c||}
\hline & & muito ruim & ruim & $\begin{array}{c}\text { nem ruim } \\
\text { nem bom }\end{array}$ & bom muito bom \\
\hline 15 & Quão bem você é capaz de se lpcomover? & 1 & 2 & 3 & 4 & 5 \\
\hline
\end{tabular}

\begin{tabular}{|c|c|c|c|c|c|c|}
\hline & & $\begin{array}{c}\text { muito } \\
\text { insatisfeito }\end{array}$ & insatisfeito & $\begin{array}{l}\text { nem satisfeito } \\
\text { nem insatisfeito }\end{array}$ & satisfeito & $\begin{array}{c}\text { muito } \\
\text { satisfeito }\end{array}$ \\
\hline 16 & $\begin{array}{l}\text { Quão satisfeito(a) você está com } \\
\text { o seu sono? }\end{array}$ & 1 & 2 & 3 & 4 & 5 \\
\hline 17 & $\begin{array}{l}\text { Quão satisfeito(a) você está com } \\
\text { sua capacidade de desempenhar as } \\
\text { atividades do seu dia-a-dia? }\end{array}$ & 1 & 2 & 3 & 4 & 5 \\
\hline 18 & $\begin{array}{l}\text { Quão satisfeito(a) você está com } \\
\text { sua capacidade para o trabalho? }\end{array}$ & 1 & 2 & 3 & 4 & 5 \\
\hline 19 & $\begin{array}{l}\text { Quão satisfeito(a) você está consigo } \\
\text { mesmo? }\end{array}$ & 1 & 2 & 3 & 4 & 5 \\
\hline 20 & $\begin{array}{l}\text { Quão satisfeito(a) você está com suas } \\
\text { relações pessoais (amigos, parentes, } \\
\text { conhecideos, colegas) }\end{array}$ & 1 & 2 & 3 & 4 & 5 \\
\hline 21 & $\begin{array}{l}\text { Quão satisfeito(a) você está com sua } \\
\text { vida sexual? }\end{array}$ & 1 & 2 & 3 & 4 & 5 \\
\hline 22 & $\begin{array}{c}\text { Quão satisfeito(a) você está com o apoio } \\
\text { que você recebe de seus amigos? }\end{array}$ & 1 & 2 & 3 & 4 & 5 \\
\hline 23 & $\begin{array}{l}\text { Quão satisfeito(a) você está com as } \\
\text { condições do local onde mora? }\end{array}$ & 1 & 2 & 3 & 4 & 5 \\
\hline 24 & $\begin{array}{l}\text { Quão satisfeito(a) você está com o seu } \\
\text { acesso aos services de saúde? }\end{array}$ & 1 & 2 & 3 & 4 & 5 \\
\hline 25 & $\begin{array}{l}\text { Quão satisfeito(a) você está com o seu } \\
\text { meio de transporte? }\end{array}$ & 1 & 2 & 3 & 4 & 5 \\
\hline
\end{tabular}

As questões seguintes referem-se a com que freqüência você sentiu ou experimentou certas coisas nas últimas duas semanas.

\begin{tabular}{||c|c|c|c|c|c|c||}
\hline & nunca & Algumas vezes & freqüentemente & $\begin{array}{c}\text { muito } \\
\text { freqüentemente }\end{array}$ & sempe \\
\hline 26 & $\begin{array}{c}\text { Com que freqüência você tem sentimentos } \\
\text { negativos tais como mau humor, } \\
\text { desespero, ansiedade, depressão? }\end{array}$ & 1 & 2 & 3 & 4 & 5 \\
\hline
\end{tabular}

Alguém lhe ajudou a preencher este questionário?.

Quanto tempo você levou para preencher este questionário?.....

Você tem algum comentário sobre o questionário? OBRIGADO PELA SUA COLABORAÇÃO 


\section{CENTER FOR EPIDEMIOLOGIC STUDIES-DEPRESSION SCALE (CES-D)}

Instruções: Abaixo há uma lista de sentimentos e comportamentos. Por favor, assinale a frequência com que lhe ocorrem na última semana.

(1) Raramente ou nunca (menos que 1 dia)

(2) Poucas vezes (1-2 dias)

(3) Às vezes (3-4 dias)

(4) Quase sempre ou sempre (5-7 dias)

Durante a última semana:

( ) Eu me chateei por coisas que não me chateavam.

( ) Não tive vontade de comer; estava sem apetite.

( ) Sinto que não consegui me livrar da tristeza mesmo com a ajuda da minha família ou dos meus amigos.

( ) Eu me senti tão bem quanto as outras pessoas.

( ) Eu tive problemas para manter a concentração (prestar atenção) no que estava fazendo.

( ) Eu me senti deprimido.

( ) Sinto que tudo que eu fiz foi muito custoso.

( ) Eu me senti com esperança em relação ao futuro.

( ) Eu pensei que minha vida tem sido um fracasso.

( ) Eu me senti com medo.

( ) Meu sono esteve agitado.

( ) Eu estive feliz.

( ) Eu conversei menos que o meu normal.

( ) Eu me senti sozinho.

( ) As pessoas não foram amigáveis.

( ) Eu me diverti.

( ) Eu tive crises de choro.

( ) Eu me senti triste.

( ) Eu senti que as pessoas não gostam de mim.

( ) Eu me sinto desanimado.

\section{Submit or recommend next manuscript to SCIRP and we will provide best service for you:}

Accepting pre-submission inquiries through Email, Facebook, LinkedIn, Twitter, etc.

A wide selection of journals (inclusive of 9 subjects, more than 200 journals)

Providing 24-hour high-quality service

User-friendly online submission system

Fair and swift peer-review system

Efficient typesetting and proofreading procedure

Display of the result of downloads and visits, as well as the number of cited articles

Maximum dissemination of your research work

Submit your manuscript at: http://papersubmission.scirp.org/ 